\title{
Insights into the invasion biology of Plasmodium vivax
}

\section{Surendra K. Prajapati* and Om P. Singh}

Department of Molecular Biology, National Institute of Malaria Research, New Delhi, India

*Correspondence: surendramrc@gmail.com

Edited by:

Robert Heinzen, NIH/NIAID-RML, USA

Reviewed by:

Robert Heinzen, NIH/NIAID-RML, USA

Plasmodium vivax is the most widely distributed human malaria parasite outside sub Sahara regions of Africa causing huge morbidity and occasionally being severe and fatal (Kochar et al., 2005; Tjitra et al., 2008). Invasion of host erythrocytes is essential for development of disease and the process varies greatly among different malaria parasites. Merozoites of $P$. vivax and $P$. berghei (a rodent malaria parasite) primarily invade reticulocytes (Kitchen, 1938; Cromer et al., 2006) whereas P. falciparum invades both reticulocytes and mature erythrocytes (Pasvol et al., 1980; Mitchell et al., 1986).

Erythrocyte invasion by malaria parasites is a complex and multi-step process involving interaction between parasite ligands and host cell receptors. The molecules involved in host-parasite interactions of $P$. falciparum are well characterized and engage multiple invasion pathways (Hadley et al., 1987; Cowman and Crabb, 2006). Conversely, hostparasite interactions of $P$. vivax are poorly understood. Erythrocyte invasion by $P$. vivax is mediated by a single receptor expressed on the surface of erythrocytes and reticulocytes called Duffy receptor, or Duffy antigen receptor for chemokines (DARC) (Horuk et al., 1993). During the invasion process, Duffy receptor is recognized and bound by Duffy binding protein (DBP) of $P$. vivax. DBP is a $140 \mathrm{kD}$ protein located within micronemes of merozoites (Fang et al., 1991; Adams et al., 1992) and it belongs to the family of Duffy binding like erythrocyte binding proteins (DBL-EBP). DBP is comprised of five regions based on conserved cysteine residues, and region II confers adherence to Duffy receptor on the erythrocyte surface. The absence of Duffy receptor (Duffy negative trait) confers resistance to P. vivax infection (Miller et al., 1976). The Duffy negative trait is conferred by a point mutation in the promoter region of the Duffy receptor gene, which abolishes erythroid expression of this receptor (Tournamille et al., 1995). Fixation of the Duffy negativity trait, and the absence of $P$. vivax infection in human populations of the African continent, supports the hypothesis suggesting that $P$. vivax cannot infect Duffy negative individuals (Miller et al., 1976).

In addition to DBP, other $P$. vivax proteins involved in recognition and binding of reticulocytes have been identified, however, their respective receptors on reticulocytes are not defined. These parasite proteins include reticulocyte-binding proteins (RBP) and merozoite surface protein1 (MSP-1) (Galinski et al., 1992; Cantor et al., 2001; Rodriguez et al., 2002). The specificity in binding of reticulocytes is conferred by the RBP family. Members of the RBP family are found in malaria parasites of humans, simians, and rodents (Galinski et al., 1992; Keen et al., 1994; Rayner et al., 2000, 2004). Major functions of RBPs can be observed during the initial process of erythrocyte selection/recognition and invasion (Galinski et al., 1992). Two members (RBP-1 and RBP-2) of the RBP family have been characterized so far from $P$. vivax and are promising vaccine candidates (Galinski and Barnwell, 1996). However, genome sequences of several malaria parasites of human, primate, and rodent have revealed many putative RBP family-like genes. Comparative genetic analysis of members of the RBP family suggests that the family is highly evolved and conserved across malarial parasites where each parasite species encodes a range of 4-15 members (Aurrecoechea et al., 2009). P. vivax encodes 11 members of the RBP gene family that are believed to provide recognition and specificity in the reticulocyte binding process. Characterization of DNA sequence polymorphisms of a few members of the RBP gene family from worldwide field isolates (Rayner et al., 2005; Kosaisavee et al., 2012; Prajapati et al., 2012) reveals a level of genetic polymorphisms commonly observed in promising vaccine candidate genes of malarial parasites. This suggests that members of RBP are recognized by the host immune system.

Interestingly, several recent reports show infection of $P$. vivax in Duffynegative individuals in African (Ryan et al., 2006; Mendes et al., 2011; Wurtz et al., 2011) and American continents (Cavasini et al., 2007a,b; Carvalho et al., 2012). These reports are highly intriguing considering the presumed dependence of $P$. vivax on Duffy receptor for invasion. Thus, Duffy receptor may not be the only gateway for $P$. vivax and alternative invasion mechanisms may exist (Mons, 1990). It is important to understand how, and under what circumstances, $P$. vivax infects to Duffy negative individuals.

$P$. vivax is the only human malaria parasite that invades reticulocytes. Each of the 11 proteins encoded by the RBP gene family has a cognate receptor on the surface of reticulocytes that is essential for $P$. vivax invasion. Therefore, understanding the invasion biology of $P$. vivax requires functional characterization of RBPs and their receptor on the reticulocyte surface. Unlike P. falciparum, the study of $P$. vivax is associated with technical and experimental difficulties that have impeded progress in understanding aspects of parasite genetics, such as population genetics. A major technical problem with $P$. vivax is the lack of an in vitro culture system. Other experimental constraints include the need of ample reticulocytes for long-term culture, a poor understanding of the biology of reticulocytes and their receptors, and a remarkably low parasitemia in $P$. vivax-infected 
individuals. Consequently, functional studies aiming to uncover various aspects of $P$. vivax biology such as invasion, reproduction, virulence, and development are poorly understood.

Despite these limitations, extensive efforts aimed at developing a continuous culture system for $P$. vivax have resulted in establishment of short-term in vitro invasion and maturation assays (Chotivanich et al., 2001; Udomsangpetch et al., 2007; Russell et al., 2008), in addition to a methods for cryopreservation of both $P$. vivax and cord blood reticulocytes (Borlon et al., 2012). These advances provide important tools for unraveling the unique biology of $P$. vivax invasion, such as identifying receptors for RBPs on reticulocytes using pull-down assays. This kind of study would not only uncover molecular mechanism underlying invasion biology but also open new avenues to look for alternative routes for $P$. vivax invasion.

Considering $P$. vivax can infect Duffy negative individuals, functional characterization of RBPs and their receptors on reticulocytes will provide new insights into the biology of $P$. vivax invasion. Given that $P$. vivax cannot invade mature erythrocytes, understanding the role of RBPs in invasion process is critical for developing a new generation of treatment therapies.

\section{ACKNOWLEDGMENTS}

This work was supported by an ICMRPostdoctoral Fellowship program of the Indian Council of Medical Research (ICMR), New Delhi, India. Surendra K. Prajapati is an ICMR-Postdoctoral Fellow.

\section{REFERENCES}

Adams, J. H., Sim, B. K., Dolan, S. A., Fang, X., Kaslow, D. C., and Miller, L. H. (1992). A family of erythrocyte binding proteins of malaria parasites. Proc. Natl. Acad. Sci. U.S.A. 89, 7085-7089.

Aurrecoechea, C., Brestelli, J., Brunk, B. P., Dommer, J., Fischer, S., Gajria, B., et al. (2009). PlasmoDB: a functional genomic database for malaria parasites. Nucleic Acids Res. 37, D539-D543.

Borlon, C., Russell, B., Sriprawat, K., Suwanarusk, R., Erhart, A., Renia, L., et al. (2012). Cryopreserved Plasmodium vivax and cord blood reticulocytes can be used for invasion and short term culture. Int. J. Parasitol. 42, 155-160.

Cantor, E. M., Lombo, T. B., Cepeda, A., Espinosa, A. M., Barrero, C. A., Guzman, F., et al. (2001). Plasmodium vivax: functional analysis of a highly conserved PvRBP-1 protein region. Mol. Biochem. Parasitol. 117, 229-234.
Carvalho, T. A., Queiroz, M. G., Cardoso, G. L., Diniz, I. G., Silva, A. N., Pinto, A. Y., et al. (2012). Plasmodium vivax infection in Anajas, State of Para: no differential resistance profile among Duffy-negative and Duffy-positive individuals. Malar. J. 11:430. doi: 10.1186/1475-287511-430

Cavasini, C. E., De Mattos, L. C., Couto, A. A., Couto, V. S., Gollino, Y., Moretti, L. J., et al. (2007a). Duffy blood group gene polymorphisms among malaria vivax patients in four areas of the Brazilian Amazon region. Malar. J. 6:167. doi: 10.1186/14752875-6-167

Cavasini, C. E., Mattos, L. C., Couto, A. A., BoniniDomingos, C. R., Valencia, S. H., Neiras, W. C., et al. (2007b). Plasmodium vivax infection among Duffy antigen-negative individuals from the Brazilian Amazon region: an exception? Trans. R. Soc. Trop. Med. Hyg. 101, 1042-1044.

Chotivanich, K., Silamut, K., Udomsangpetch, R., Stepniewska, K. A., Pukrittayakamee, S., Looareesuwan, S., et al. (2001). Ex-vivo shortterm culture and developmental assessment of Plasmodium vivax. Trans. R. Soc. Trop. Med. Hyg. 95, 677-680.

Cowman, A. F., and Crabb, B. S. (2006). Invasion of red blood cells by malaria parasites. Cell 124, 755-766.

Cromer, D., Evans, K. J., Schofield, L., and Davenport, M. P. (2006). Preferential invasion of reticulocytes during late-stage Plasmodium berghei infection accounts for reduced circulating reticulocyte levels. Int. J. Parasitol. 36, 1389-1397.

Fang, X. D., Kaslow, D. C., Adams, J. H., and Miller, L. H. (1991). Cloning of the Plasmodium vivax Duffy receptor. Mol. Biochem. Parasitol. 44, 125-132.

Galinski, M. R., and Barnwell, J. W. (1996). Plasmodium vivax: merozoites, invasion of reticulocytes and considerations for malaria vaccine development. Parasitol. Today 12, 20-29.

Galinski, M. R., Medina, C. C., Ingravallo, P., and Barnwell, J. W. (1992). A reticulocyte-binding protein complex of Plasmodium vivax merozoites. Cell 69, 1213-1226.

Hadley, T. J., Klotz, F. W., Pasvol, G., Haynes, J. D., McGinniss, M. H., Okubo, Y., et al. (1987). Falciparum malaria parasites invade erythrocytes that lack glycophorin A and B (MkMk). Strain differences indicate receptor heterogeneity and two pathways for invasion. J. Clin. Invest. 80, 1190-1193.

Horuk, R., Chitnis, C. E., Darbonne, W. C., Colby, T. J., Rybicki, A., Hadley, T. J., et al. (1993). A receptor for the malarial parasite Plasmodium vivax: the erythrocyte chemokine receptor. Science 261, 1182-1184.

Keen, J. K., Sinha, K. A., Brown, K. N., and Holder, A. A. (1994). A gene coding for a high-molecular mass rhoptry protein of Plasmodium yoelii. Mol. Biochem. Parasitol. 65, 171-177.

Kitchen, S. F. (1938). The infection of reticulocytes by Plasmodium vivax. Am. J. Trop. Med. Hyg. 18, 347-353.

Kochar, D. K., Saxena, V., Singh, N., Kochar, S. K., Kumar, S. V., and Das, A. (2005). Plasmodium vivax malaria. Emerg. Infect. Dis. 11, 132-134.

Kosaisavee, V., Lek-Uthai, U., Suwanarusk, R., Gruner, A. C., Russell, B., Nosten, F., et al. (2012). Genetic diversity in new members of the reticulocyte binding protein family in Thai Plasmodium vivax isolates. PLoS ONE 7:e32105. doi: 10.1371/journal.pone.0032105

Mendes, C., Dias, F., Figueiredo, J., Mora, V. G., Cano, J., De Sousa, B., et al. (2011). Duffy negative antigen is no longer a barrier to Plasmodium vivaxmolecular evidences from the African West Coast (Angola and Equatorial Guinea). PLoS Negl. Trop. Dis. 5:e1192. doi: 10.1371/journal.pntd.0001192

Miller, L. H., Mason, S. J., Clyde, D. F., and McGinniss, M. H. (1976). The resistance factor to Plasmodium vivax in blacks. The Duffy-blood-group genotype, FyFy. N. Engl. J. Med. 295, 302-304.

Mitchell, G. H., Hadley, T. J., McGinniss, M. H., Klotz, F. W., and Miller, L. H. (1986). Invasion of erythrocytes by Plasmodium falciparum malaria parasites: evidence for receptor heterogeneity and two receptors. Blood 67, 1519-1521.

Mons, B. (1990). Preferential invasion of malarial merozoites into young red blood cells. Blood Cells 16, 299-312.

Pasvol, G., Weatherall, D. J., and Wilson, R. J. (1980). The increased susceptibility of young red cells to invasion by the malarial parasite Plasmodium falciparum. Br. J. Haematol. 45, 285-295.

Prajapati, S. K., Kumari, P., and Singh, O. P. (2012). Molecular analysis of reticulocyte binding protein2 gene in Plasmodium vivax isolates from India. BMC Microbiol. 12:243. doi: 10.1186/1471-218012-243

Rayner, J. C., Galinski, M. R., Ingravallo, P., and Barnwell, J. W. (2000). Two Plasmodium falciparum genes express merozoite proteins that are related to Plasmodium vivax and Plasmodium yoelii adhesive proteins involved in host cell selection and invasion. Proc. Natl. Acad. Sci. U.S.A. 97, 9648-9653.

Rayner, J. C., Huber, C. S., Galinski, M. R., and Barnwell, J. W. (2004). Rapid evolution of an erythrocyte invasion gene family: the Plasmodium reichenowi Reticulocyte Binding Like (RBL) genes. Mol. Biochem. Parasitol. 133, 287-296.

Rayner, J. C., Tran, T. M., Corredor, V., Huber, C. S., Barnwell, J. W., and Galinski, M. R. (2005). Dramatic difference in diversity between Plasmodium falciparum and Plasmodium vivax reticulocyte binding-like genes. Am. J. Trop. Med. Hyg. 72, 666-674.

Rodriguez, L. E., Urquiza, M., Ocampo, M., Curtidor, H., Suarez, J., Garcia, J., et al. (2002). Plasmodium vivax MSP-1 peptides have high specific binding activity to human reticulocytes. Vaccine 20, 1331-1339.

Russell, B., Chalfein, F., Prasetyorini, B., Kenangalem, E., Piera, K., Suwanarusk, R., et al. (2008). Determinants of in vitro drug susceptibility testing of Plasmodium vivax. Antimicrob. Agents Chemother. 52, 1040-1045.

Ryan, J. R., Stoute, J. A., Amon, J., Dunton, R. F., Mtalib, R., Koros, J., et al. (2006). Evidence for transmission of Plasmodium vivax among a duffy antigen negative population in Western Kenya. Am. J. Trop. Med. Hyg. 75, 575-581.

Tjitra, E., Anstey, N. M., Sugiarto, P., Warikar, N., Kenangalem, E., Karyana, M., et al. (2008). Multidrug-resistant Plasmodium vivax associated 
with severe and fatal malaria: a prospective study in Papua, Indonesia. PLoS Med. 5:e128. doi: 10.1371/journal.pmed.0050128

Tournamille, C., Colin, Y., Cartron, J. P., and Le Van Kim, C. (1995). Disruption of a GATA motif in the Duffy gene promoter abolishes erythroid gene expression in Duffy-negative individuals. Nat. Genet. 10, 224-228.

Udomsangpetch, R., Somsri, S., Panichakul, T., Chotivanich, K., Sirichaisinthop, J., Yang, Z., et al. (2007). Short-term in vitro culture of field isolates of Plasmodium vivax using umbilical cord blood. Parasitol. Int. 56, 65-69.

Wurtz, N., Mint Lekweiry, K., Bogreau, H., Pradines, B., Rogier, C., Ould Mohamed Salem Boukhary, A., et al. (2011). Vivax malaria in Mauritania includes infection of a Duffy-negative individual. Malar. J. 10:336. doi: 10.1186/1475-2875-10-336

Received: 28 January 2013; accepted: 16 February 2013; published online: 05 March 2013.
Citation: Prajapati SK and Singh OP (2013) Insights into the invasion biology of Plasmodium vivax. Front. Cell. Infect. Microbiol. 3:8. doi: 10.3389/fcimb. 2013.00008

Copyright (c) 2013 Prajapati and Singh. This is an open-access article distributed under the terms of the Creative Commons Attribution License, which permits use, distribution and reproduction in other forums, provided the original authors and source are credited and subject to any copyright notices concerning any thirdparty graphics etc. 